\title{
Integrated Assessment of Groundwater Pollution from the Landfill of Sewage Sludge
}

\author{
Andrey Mikhailovich Dregulo ${ }^{1,2}$, Nikolai Gennadievich Bobylev \\ 1 Federal State Budgetary Educational Institution of Higher Education "Saint-Petersburg State University", \\ 7-9 Universitetskaya emb., 199034, Saint-Petersburg, Russia \\ 2 Scientific Research Center for Ecological Safety of the Russian Academy of Sciences, 18 Korpusnaya str.197110, \\ Saint- Petersburg, Russia \\ * Corresponding author's e-mail: a.dregulo@spbu.ru
}

\begin{abstract}
The purpose of this study was to assess the groundwater contamination from a sewage sludge landfill. The analysis was carried out in 2017 in accordance with the requirements of the national legislation for monitoring landfills and priority pollutants. The samples of groundwater from the landfill were taken from 25 observation wells, from depths of $45-60 \mathrm{~m}$. The status and dynamics of changes in the landfill groundwater quality were estimated according to the data from the groundwater observation wells of the city observation network with regard to the chemical composition of groundwater and national standards of groundwater quality. The forecast estimates of a low level of pollutants entering groundwater through the soils characterized by low filtration properties were not justified. The concentration of heavy metals in groundwater was within the following range: $\mathrm{Fe}>\mathrm{Mn}>\mathrm{Zn}>\mathrm{Al}>\mathrm{Cu}>\mathrm{Ni}>\mathrm{Pb}>$ $\mathrm{Cd}>\mathrm{Hg}$. The excess concentration of the nitrogen-containing pollutants was observed within the range from 1.5 to 76 (on average 10 times) above the background value. The organic contamination of landfill groundwater (COD) is 2-9 times and $\mathrm{BOD}_{5}-1.5-3$ times higher than the average background value of groundwater observation wells in the city network. The probable cause for the pollutants entry into groundwater is associated with lithogenous and exogenous fracturing of the rocks and insufficient efficiency of the existing anti-filtration system of the landfill.
\end{abstract}

Keywords: landfill, sewage sludge, groundwater, heavy metals, organic pollution, fecal coliform bacteria, the Gulf of Finland

\section{INTRODUCTION}

The main problem of negative consequences from waste deposits is the inflow of filtrate into the soil and groundwater [Spinosa 2007; Brennan et al. 2017; Przydatek and Kanownik 2019]. There is a list of parameters determining the hazard degree of wastewater precipitation (the content of heavy metals, organic pollutants, and other dangerous substances) and assessing the need for their disposal at landfills [Conti and Cecchetti 2001; Donatello et al. 2010; Bjerg et al. 2003; Burkhard and Maes 2017; Dregulo and Bobylev 2021; Dregulo et al. 2019].

Researchers often focus on the agronomic value of sewage sludge as a biological substrate for restoring soil fertility [Wei and Liu 2005; Song and Lee 2010; Casado-Vela et al. 2007; Chiu et al. 2006]. This approach does not allow identifying the environmental hazards associated with ecosystem contamination (subsoil and underground water) during the long-term deposition of sewage sludge [Dregulo and Vitkovskaya 2018; Wang, et al. 2013; Zeng et al. 2012; O'Kelly 2005].

For some period of time, even mineralization processes, heavy metals can be released and form new compounds with the soil humic substances. Precipitation plays an important role [Dregulo 2019], which increases the humidity of sewage precipitation. In this case, unstable compounds dissociate to form the cation-anion complexes capable of a long migration path [Chabuk et al. 2018; Abd El-Salam and I Abu-Zuid 2015; Naveen et al. 2018; Luczkiewicz 2006]. 
Another important criterion for the landfill safe operation is the low filtration properties of soils and the groundwater depth. These criteria allow considering the selected area as environmentally safe.

In our opinion, it is not enough to rely only on the theoretical (design) conclusions of the environmental expertise in order to make sure that the landfill is protected from the negative impact and environmental harm. The possible manifestations of environmental imbalances should be further studied. This is especially important in the case of a long-term use of the landfill.

The Russian legislation makes it difficult to conduct an independent environmental assessment of landfill operation, since it does not provide for any inventory of waste disposal facilities included in the State register of waste disposal facilities, as well as for the waste disposal facilities that are not included in this register, but the operation of which has not been completed and have an owner who operates them [Methodological recommendations... 2013]. This largely determines the formal approach of the regulatory and legal sphere, regulating the activities of wastewater disposal at the landfills in Russia [Dregulo and Kudryavtsev 2018].

\section{MATERIAL AND METHODS}

\section{Research object}

The "Severny" landfill is located in the urban agglomeration of Saint Petersburg $\left(60^{\circ} 4.714\right.$. $\left.30^{\circ} 9.808\right)$. It was put into operation in 1984 . Until 1984, there were drying beds on the territory of the landfill. According to the existing recycling scheme, the sludge was dewatered in centrifuges by using cationic flocculant and deposited at the landfill. Every year, about 200 thousand $\mathrm{m}^{3}$ of uninfected, unstable sediment was exported to the landfill. By the early 1990s, the landfill was approximately $70 \%$ full. If the rate of landfills filling (storing sediment) were maintained, the free areas of the landfill would have been filled by the early 2000 s. The area of the landfill is 83 hectares. The landfill consists of drying beds up to $2 \mathrm{~m}$ deep and $6 \mathrm{~m}$ deep slime collectors. Untreated sewage sludge (until 2003), sewage sludge treated in drying geological tubes and ash from burning sewage sludge (from 2007 to the present) were deposited on drying beds and sludge collectors. Since 2007, the landfill has disposed of the ash from burning sewage sludge. Sewage sludge collectors are equipped with a screen made of Carbofol HDPE 406 Friction $1.5 \mathrm{~mm}$ thick anti-filtration material, laid on a crushed stone base with protective sand and Cambrian clay layer, which is up to $1 \mathrm{~m}$ thick.

\section{The geological and lithological structure}

The file information allowed us to characterize the ground water horizon in the area of the landfill location. The water-bearing horizon belongs to the Moscow-Ostashkovsky (Upper, or Polyustrovsky) inter-sea water-bearing horizon. The horizon lies under the sediments of the Ostashkovsky moraine on pre-quaternary rocks and is composed of the sand-gravel lake and water-glacial deposits. The depth varies from $2-5$ to $40-60 \mathrm{~m}$. The thickness of the horizon varies from parts of a meter to $65 \mathrm{~m}$, the most common is $15-30 \mathrm{~m}$ [Solovyova 1984].

The variety of sedimentation conditions determines the facial differences in the granulometric composition of water-bearing rocks: from fine and dusty sands to coarse sands with gravel and pebbles. The water-bearing horizon is fed by the flow of groundwater from the above-lying layers through hydrogeological "windows" in the areas where there are no overlapping boulder stained loams. The structure of soils is shown in Figure 2. Loams and Cambrian clays have low filtration properties [O'Geen 2013].

Sampling from the observation wells of the landfill is carried out by bailer with pre-pumping. In 2017, the groundwater observations were conducted on 25 observation wells of the landfill (Fig. 3). Observation wells were pumped to ensure the flow of "fresh" water to the filter zone. The amount of pumped water is at least two volumes of the well water column. The volume of the water sample taken is not less than $1000 \mathrm{~cm}$. The groundwater temperature was measured by using a mercury thermometer. The measurements were performed throughout the calendar year. SPSS Statistics 22, Surfer 13, and Grapher 11 were used for statistical data processing.

\section{Groundwater pollution assessment}

The state and dynamics of changes in the quality of groundwater were assessed by using file materials of groundwater observation wells in the city network for monitoring the chemical 


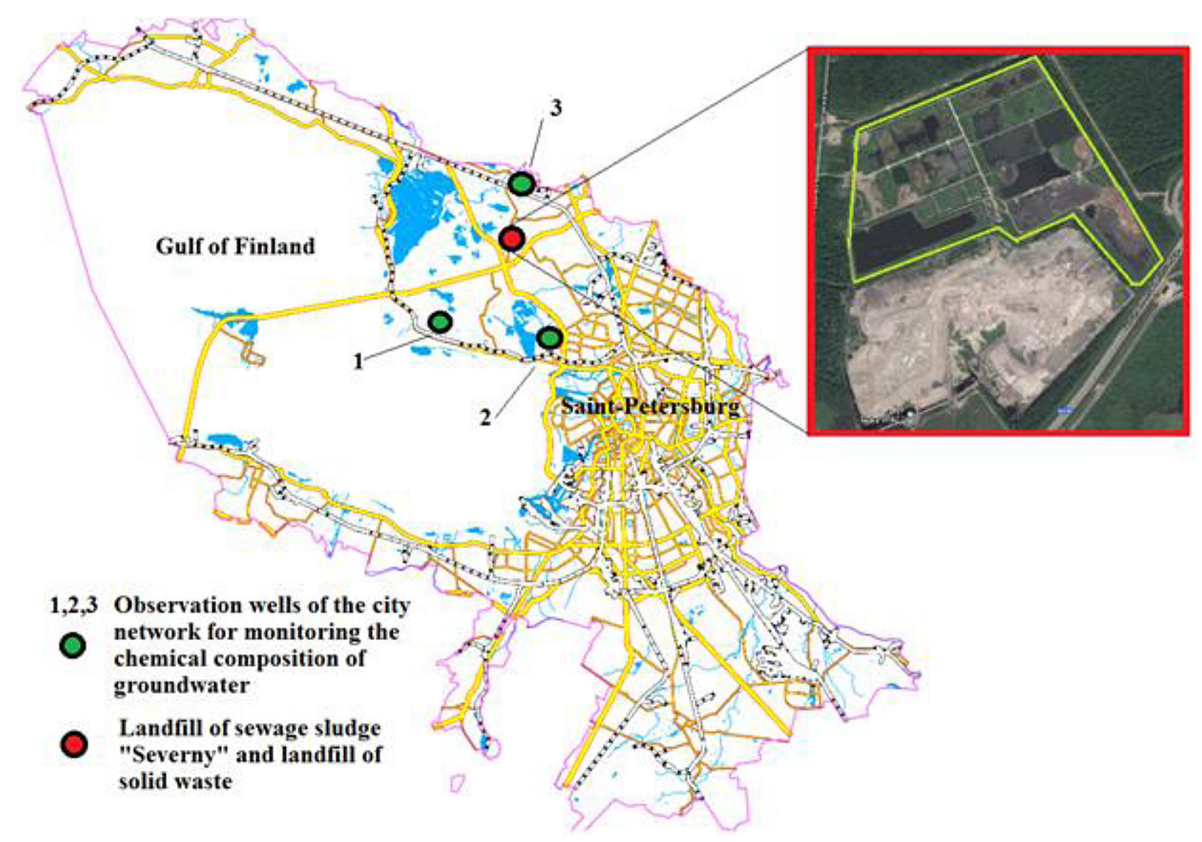

Fig. 1. "Severny" sewage sludge landfill (marked) and the solid waste deposit landfill

composition of groundwater located near the "Severny" landfill (Table 1) [Report "Conducting state monitoring of the geological environment of St. Petersburg in 2017" 2018]. The content of heavy metals in groundwater was determined by means of atomic absorption spectrometry. For this purpose, an unfiltered mixed water sample was subjected to acid salting in a water bath, $2.5 \mathrm{~cm}^{3}$ of concentrated nitric acid was added to $50 \mathrm{~cm}^{3}$ of the analyzed water and evaporated to wet salts. Then $20 \mathrm{~cm}^{3}$ of distilled water was added, the solution was mixed and filtered through a paper filter. The measurements were carried out by an A-2 Aquilon atomic absorption spectrometer (spectral range from 190 to $900 \mathrm{~nm}$ with a resolution of $0.2 \pm 0.02 \mathrm{~nm}$ ). The chemical oxygen demand (COD) and biochemical oxygen demand $\left(\mathrm{BOD}_{5}\right)$ measurements were carried out by using the titrimetric method. The water samples were treated with sulfuric acid and potassium bichromate at a given temperature in the presence of

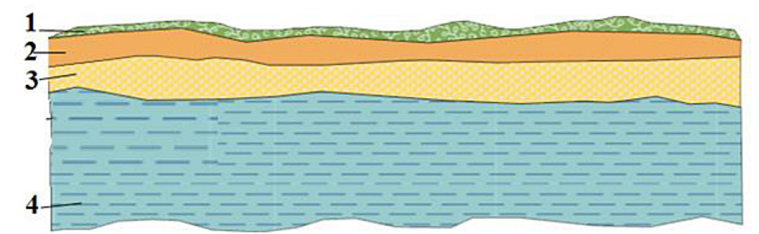

1) Soil and vegetation layer $0.2 \mathrm{~m}$

2) Loam lake-glacial refractory $3 \mathrm{~m}$

3) Sandy $5 \mathrm{~m}$; 4) Cambrian clay $20-50 \mathrm{~m}$

Fig. 2. Geological a section of the landfill silver sulfate, an oxidation catalyst, and mercury (II) sulfate, used to reduce the effect of chlorides and determining the COD values in a given concentration range.

Then the optical density of the test solution was measured at a given wavelength. The concentrations of ammonia and ammonium ions were measured by using a photo-colorimetric method at a wavelength of $400-425 \mathrm{~nm}$. The study of total phosphorus content is based on the oxidation of all phosphorus-containing compounds to orthophosphates when boiling a sample with potassium persulfate in an acidic environment. The content of orthophosphates in the resulting solution is determined by means of the photometric method, after the appearance of molybdenum

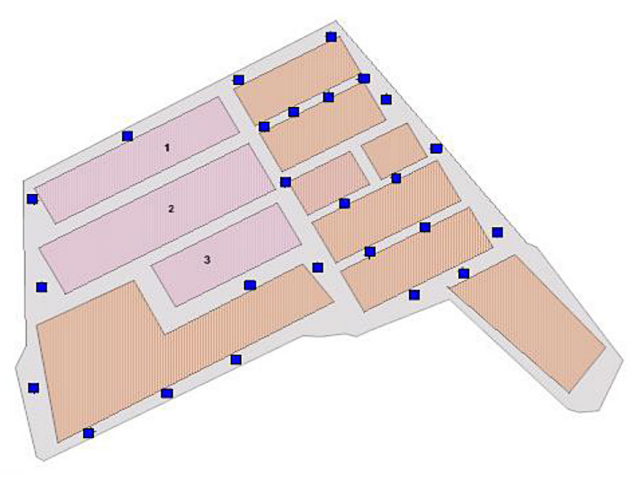

1,2,3- parts of the landfill operated from 1984-2003 Slurry pit Wells for groundwater extraction

Fig. 3. The structure of the landfill and groundwater sampling points 
Table 1. Background content of chemical components in groundwater $\left(\mathrm{mg} / \mathrm{dm}^{3}\right)$

\begin{tabular}{|c|c|c|c|c|c|c|c|c|c|c|c|c|c|c|c|c|c|c|c|c|c|c|c|c|}
\hline \multirow{2}{*}{$\begin{array}{c}\text { Compo- } \\
\text { nents }\end{array}$} & \multicolumn{8}{|c|}{ Well 1} & \multicolumn{8}{|c|}{ Well 2} & \multicolumn{8}{|c|}{ Well 3} \\
\hline & 2010 & 2011 & 2012 & 2013 & 2014 & 2015 & 2016 & 2017 & 2010 & 2011 & 2012 & 2013 & 2014 & 2015 & 2016 & 2017 & 2010 & 2011 & 2012 & 2013 & 2014 & 2015 & 2016 & 2017 \\
\hline $\mathrm{pH}$ & - & - & 8 & - & - & - & 8.7 & 7.7 & 7.6 & 7.6 & 7.7 & 7.5 & - & - & 8.3 & 7.8 & 7.4 & 7.4 & - & - & - & 8 & 8.4 & 7.4 \\
\hline COD & 2.1 & 2.4 & 1.6 & 1.8 & 2.7 & 2.39 & 1.63 & 1.98 & 3.3 & 7.3 & 4.5 & 3.8 & 3.8 & 4.09 & 3.59 & 4.01 & 5.3 & 3.6 & 6.4 & 4.7 & 4.33 & 4.15 & 4.28 & 5.3 \\
\hline $\mathrm{NO}_{2}^{-}$ & - & - & 0.003 & 0.003 & - & - & - & - & - & 0.003 & - & - & - & - & - & - & - & - & - & - & 0.005 & - & - & - \\
\hline $\mathrm{NH}_{4}^{+}$ & 0.22 & 0.18 & 0.23 & 0.12 & 0.18 & 0.23 & - & - & 0.34 & 0.41 & 0.38 & 0.25 & 0.33 & 0.35 & - & - & - & - & - & - & - & - & - & - \\
\hline $\mathrm{Fe}$ & 1.57 & 2.72 & 1.11 & 0.9 & 2.37 & 3 & 0.3 & 0.79 & 1.23 & 1.1 & 3.29 & 0.94 & 2.4 & 1.15 & 0.55 & 0.48 & 0.44 & 0.25 & 0.46 & 0.45 & 0.47 & - & - & 0.44 \\
\hline $\mathrm{Mn}$ & 0.046 & 0.17 & 0.057 & 0.053 & 0.055 & 0.068 & 0.057 & 0.054 & 0.11 & 0.47 & 0.16 & 0.14 & 0.17 & 0.16 & 0.17 & 0.14 & 0.35 & 3.45 & 2 & 1.34 & 0.83 & 0.44 & 0.31 & 0.35 \\
\hline $\mathrm{Cu}$ & - & 0.011 & 0.002 & 0.005 & 0.001 & - & - & - & 0.004 & 0.002 & 0.002 & - & 0.001 & - & 0.002 & - & 0.26 & 0.18 & 0.38 & 0.3 & 0.25 & 0.22 & 0.17 & 0.26 \\
\hline $\mathrm{Pb}$ & - & 0.0081 & 0.001 & 0.002 & 0.007 & - & - & 0.004 & - & - & - & - & - & - & - & - & - & 0.002 & 0.002 & - & - & -- & - & - \\
\hline $\mathrm{Ni}$ & - & - & 0.001 & - & - & - & - & - & 0.003 & - & - & 0.036 & - & - & - & - & - & - & 0.002 & - & - & - & 0.004 & - \\
\hline $\mathrm{Al}$ & 0.43 & 2.7 & 0.74 & 0.53 & 3 & 0.77 & 0.39 & 1.3 & - & - & 0.003 & - & - & - & - & - & - & & - & - & - & - & - & \\
\hline $\mathrm{Zn}$ & - & 0.016 & 0.005 & - & - & - & - & - & 0.52 & 0.038 & 2 & 0.38 & 2.3 & 0.88 & 0.67 & 0.4 & 0.17 & 3.5 & 0.17 & 0.39 & 0.12 & 0.051 & 0.028 & 0.17 \\
\hline
\end{tabular}

blue. The optical density of the colored compound was measured by using a spectrophotometer $(\lambda=882 \mathrm{~nm})$. The determination of common and thermo-tolerant coliform bacteria by means of membrane filtration with their cultivation in the Endo medium at a temperature of $37 \pm 1.0^{\circ} \mathrm{C}$, followed by differentiation by culture tests and counting the grown colonies.

\section{Results and Discussion}

Saint Petersburg is located in the area of the interface of two large structures - the Baltic shield and the Russian plate, which predetermined the features of the tectonic factor. Four systems of tectonic faults have been recorded within the city, along which palaeovalleys were formed in the bedrock of the sedimentary cover, in the upper Kotlin Vendian clays, and in the southern part of the city - in the lower Cambrian blue clays. The incision depth of a number of paleovalleys reaches $120 \mathrm{~m}$, and the area is more than $30 \%$ of the city area. Such faults determine the presence of fractures in the Vendian and lower Cambrian bedrock. The intensity of rock fracturing increases in the zones adjacent to the faults [Dashko and Volkova 2017].

Earlier studies on the contamination assessment of the landfill upper soil layer showed that the concentrations of pollutants changed in the direction of decrease [Dregulo et. al. 2019; Dregulo and Vitkovskaya 2018]. This may be due to the pollutants leaching from meltwater and their entry into the lower layers of soil and groundwater.

Groundwater is one of the main components of the water balance of the territory, as it serves as the main source of nutrition of the underlying water-bearing horizons and complexes of operational significance [Rodionov et al. 2019]. The eastern part of the Gulf of Finland is the regional basis for the drainage of water-bearing horizons and complexes in the area where the landfill is located. Despite the decrease in the pollution of the Gulf of Finland from raw sewage, the quality of water in the Gulf of Finland remains unsatisfactory [Kuuppo et al. 2006]. This may indicate the presence of other pollution sources, the identification of which is necessary to achieve the goals of protecting the Baltic sea defined by the Helsinki Convention [The Helsinki Convention 1974].

One of the most important indicators of the technogenic load of the landfill on groundwater is involves the processes of destruction of waste organic matter and leaching of the dissolved fraction into groundwater. The detected concentrations of nitrites and nitrates from the observed wells of the landfill indicate the presence of strong organic contamination in the groundwater, accompanied by ongoing processes of ammonification, and - at the same time - by low nitrification and/or possibly high denitrification (Fig. 4).

The concentrations of ammonium in the wells exceeded the background concentrations 2-27 times. The nitrite concentration from 1.5 to 76 (on average 10 times) over the background was observed. The COD values ranged from 10 to $34.7 \mathrm{mg} / \mathrm{dm}^{3}$, which is $2-9$ times higher than the average background value. The $\mathrm{BOD}_{5}$ values ranged from 1.5 to $9 \mathrm{mg} / \mathrm{dm}^{3}$. The correlation analysis of $\mathrm{COD}, \mathrm{BOD}_{5}$ and ammonium nitrogen values for all wells in the landfill revealed a direct relationship ( $\mathrm{P}<=0.05)$ (Fig. 5). 

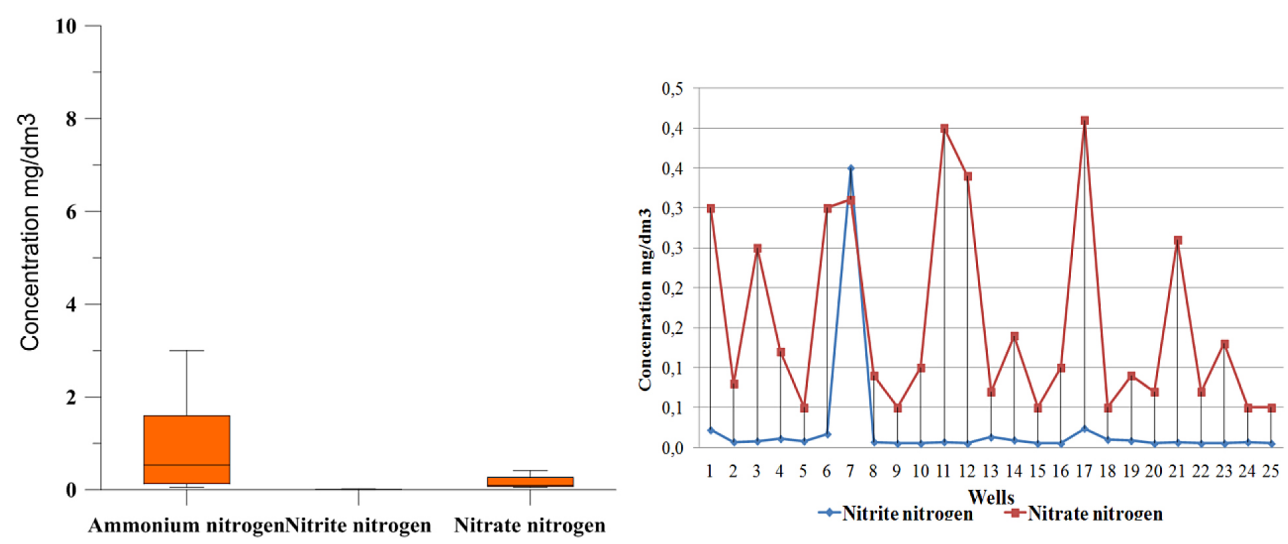

Fig. 4. Concentrations of nitrogen compounds in the landfill groundwater

In 18 wells of the landfill, the $\mathrm{NH}_{4}$ concentration ranged from 0.051 to $1.0 \mathrm{mg} / \mathrm{dm}^{3}$; from 1 to $3 \mathrm{mg} / \mathrm{dm}^{3}$ (in 5 wells of the landfill); from 3 to $9.47 \mathrm{mg} / \mathrm{dm}^{3}$ (in 2 wells of the landfill).

An increase in the $\mathrm{NH}_{4}$ concentrations in alkaline waters can inhibit the nitrification process: for the 1 st phase of nitrification in concentrations from 10 to $150 \mathrm{mg} / \mathrm{dm}^{3}$, and for the 2nd phase-in concentrations of $0.1-1.0 \mathrm{mg} / \mathrm{dm}^{3}$ [Zakhvataeva and Shelomkov 2013]. This explains the longterm degradation of $\mathrm{NH}_{4}$ in the landfill groundwater, where the $\mathrm{pH}$ values were observed in the range of $7.3-8.55$ the average value is 7.9 (Fig. 6).

Often, the conversion of organic matter during the deposition of silt deposits quickly passes on the surface of landfills, due to openness to climate influences, but it is another matter when these processes occur in the technogenic body of the landfill. Precipitation can become a conductor of pollutants for deeper water-bearing horizons, especially in the areas of close hydraulic interconnection, as evidenced by the high values of coliform bacteria (TCB) and thermotolerant coliform bacteria in groundwater (TtCB). TCB and $\mathrm{TtCB}$ belong to the group of enterobacteria, that is, intestinal bacteria, so its presence in groundwater indicates the fecal contamination (Fig. 7).

The level of TCB and TtCB contamination on the landfill territory varied significantly depending on the locations of groundwater sampling. The values of the TCB indicator for landfill groundwater ranged from 1 to $103 \mathrm{CFU} / 100 \mathrm{ml}$, which exceeded all permissible norms according to the requirements of the national legislation. According to this indicator, the groundwater is characterized as "highly polluted". The amount of TtCB was significantly lower from 1 to $10 \mathrm{CFU} / 100 \mathrm{ml}$, which corresponded to the first contamination level. The high amount of TCB and TtCB in the groundwater is most likely due to the presence of organic contamination. The groundwater contamination caused by organic matter destruction processes is closely related to the nitrification and denitrification processes and is complicated in the

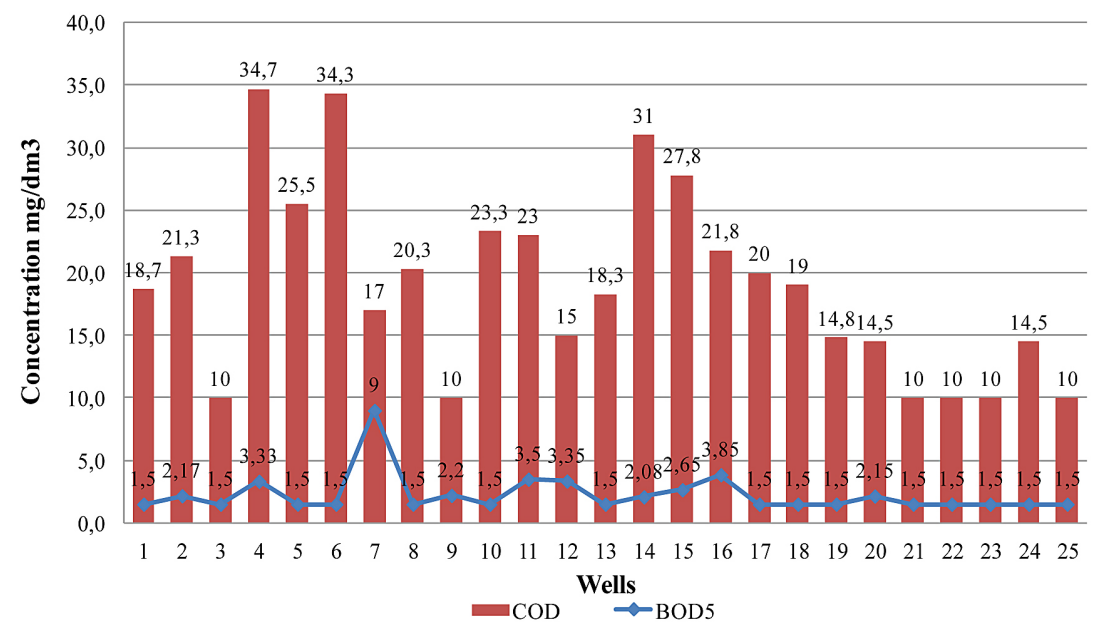

Fig. 5. Values of $\mathrm{COD}$ and $\mathrm{BOD}_{5}$ of groundwater of the landfill 


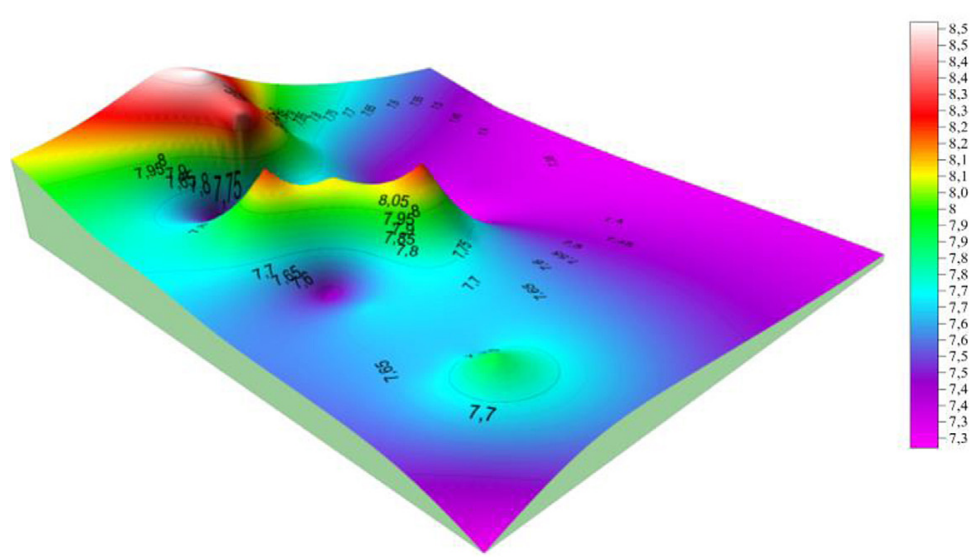

Fig. 6. The $\mathrm{pH}$ value of the groundwater of the landfill

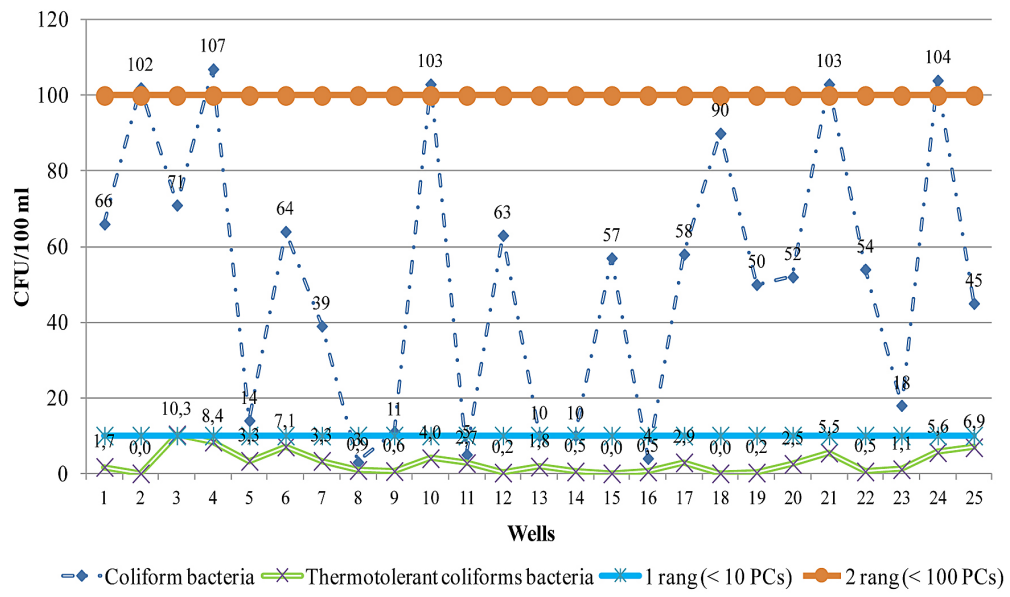

Fig. 7. The value and distribution of coliform bacteria and thermotolerant coliform bacteria in groundwater

presence of heavy metals [Lee et al. 1997; Kapoor et al. 2015]. The range of heavy metal concentrations had the following sequence: $\mathrm{Fe}>\mathrm{Mn}>\mathrm{Zn}$ $>\mathrm{Al}>\mathrm{Cu}>\mathrm{Ni}>\mathrm{Pb}>\mathrm{Cd}>\mathrm{Hg}$ (Fig. 8).

In comparison with the background concentrations, heavy metals had the following series: $\mathrm{Fe}_{10}>\mathrm{Al}_{3}>\mathrm{Mn}_{2}>\mathrm{Ni}_{2}$. The concentrations of $\mathrm{Zn}, \mathrm{Cu}, \mathrm{Pb}, \mathrm{CD}$, and $\mathrm{Hg}$ did not exceed the background values of the observation wells of the city groundwater network. Iron and aluminum predominated over other metals, probably due to the use of a cationic flocculant to treat sewage sludge based on them. The correlation analysis did not reveal the relationship of heavy metals
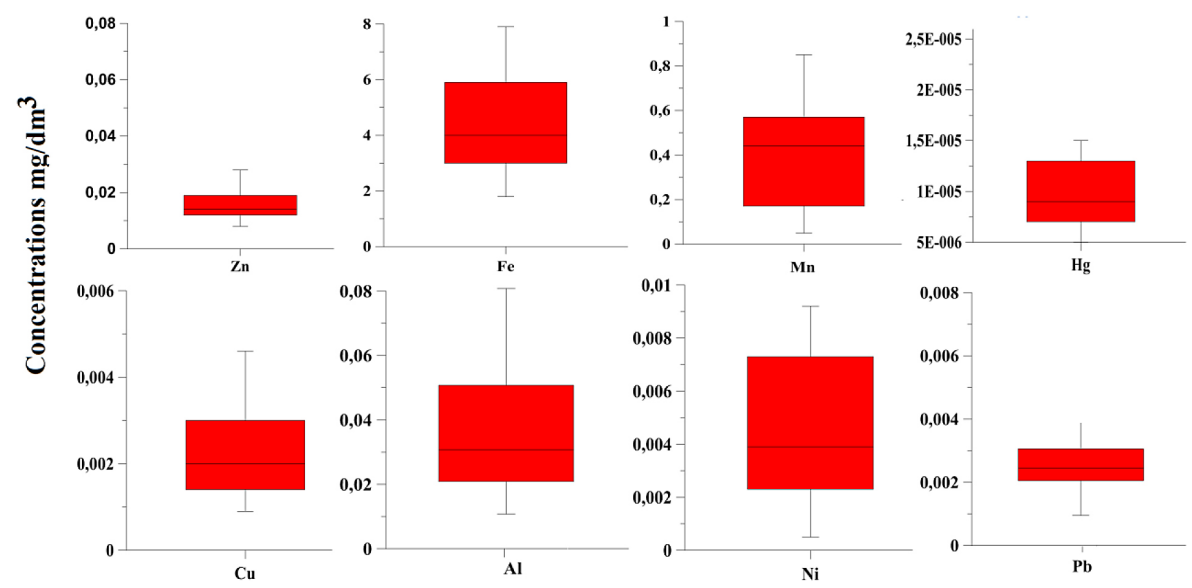

Fig. 8. Concentrations of heavy metals in groundwater 
and other polluting components $\left(\mathrm{NH}_{4}, \mathrm{TCB}\right.$, and $\mathrm{TtCB}$ ) entering the groundwater of the landfill. The most polluted areas of the "Severny" landfill were those on the north-eastern and south-eastern sides. It can be assumed that the landfill of solid household waste, which is located nearby, can affect the pollutants flow into the groundwater. The hypsometric height of the location of both landfills is the same and, therefore, the flow of pollutants into the zone of the "Severny" landfill influence should have been observed equally, including from those north-west and from the south-west side, but this was not detected.

This may be an indication that the contamination is coming unevenly and their ingress is more associated with the fracturing of the rocks.

\section{CONCLUSIONS}

On the basis of the study of groundwater contamination in the landfill area, the conclusions can be drawn as follows:

- The long-term operation of the landfill for more than 33 years causes the contamination of groundwater, even if the soil has low properties of filtrate passing;

- The groundwater quality does not meet the requirements of national legislation, the groundwater is "dirty";

- The most significant indicator of negative impact is the diffusion of pollutants into the groundwater, in particular of organic waste fraction accompanied by the nitrification processes, heavy metals, and bacteria of the coliform group;

- The groundwater quality of the considered landfill area proves that the soils with low filtration values and the effectiveness of the existing landfill anti-filtration system are insufficient for groundwater safety.

\section{Acknowledgement}

The research has been conducted with the financial support of research work "Systematization, identification and methods of assessment of objects of past environmental damage", state registration number 0241-2014-0006, Project of the Russian Foundation for Basic Research number 20-514-22001, Project of the Russian Foundation for Basic Research number 18-55-76003.

\section{REFERENCES}

1. Abd El-Salam M. M., \& I Abu-Zuid G. (2015). Impact of landfill leachate on the groundwater quality: A case study in Egypt. Journal of advanced research, 6(4), 579-586.

2. Bjerg P.L., Albrechtsen H.J Kjeldsen P., Christensen T.H., Cozzarelli I.M. 2003. The Groundwater Geochemistry of Waste Disposal Facilities Treatise on Geochemistry. Geochemistry. 9. 579-612.

3. Brennan R.B., Clifford E. Devroedt C., Morrisonb L., Healy M.G. 2017. Treatment of landfill leachate in municipal wastewater treatment plants and impacts on effluent ammonium concentrations. Journal of Environmental Management. 188, 64-72

4. Burkhard B, Maes J. (Eds) 2017. Mapping Ecosystem Services. Advanced Books. https://doi. org/10.3897/ab.e12837

5. Casado-Vela J., Selles S., Diaz-Crespo C., NavarroPedreno J., Matiax-Beneyto J., Gomez I. 2007. Effect of composted sewage sludge application to soil on sweet pepper crop (Capsicum annuum var. annuum) grow under two explotitation regimes. Waste Management 27. 1509-1518.

6. Chabuk A., Al-Ansari N., Ezz-Aldeen M., Laue J., Pusch R., Hussain H.M. Knutsson S. 2018. Two Scenarios for Landfills Design in Special Conditions Using the HELP Model: A Case Study in Babylon Governorate, Iraq. Sustainability 10, 125.

7. Chiu K.K., Ye Z.N., Wong M.N. 2006. Growth of Vetiveria zizanionides and Phragmities austails on $\mathrm{Pb} / \mathrm{Zn}$ and $\mathrm{Cu}$ mine tailings amended with manure compost and sewage sludge: a greenhouse study. Bioresource Technology 97.157-170

8. Conti, M.E. and Cecchetti, G. 2001. Biological monitoring: lichens as bioindicators of air pollution assessment - A review. Environmental pollution (Barking, Essex: 1987). 114. 471-92.

9. Dashko R. E. and Volkova A.V. 2017. Geomechanical analysis of the root clays of St. Petersburg as a fractured block medium. Notes of the Mining Institute. 156, 118, (in Russian)

10. Dregulo A. M., Pitulko V. M., Rodionov V. Z., Kulibaba, V.V., Petukhov V.V. 2019. Geoecological evaluation of environmental damage to the results of long-term dynamics of benzopyrene and petroleum within landfill sludge IOP Conference Series: Earth and Environmental Science. 321, 012037.

11. Dregulo A.M. and Vitkovskaya R.F. 2018. Microbiological evaluation of soils of sites with accumulated ecological damage (Sewage Dumps). Fiber Chemistry. 50 (3), $243-247$

12. Dregulo A.M. 2019. Identification and prediction of climatic loads for design and operation of drying beds. Water and Ecology. 24 (1), 35-43 
13. Dregulo A.M. and Kudryavtsev A.V. 2018 Transformation of techno-natural systems of water treatment to objects of past environmental damage: peculiarities of the legal and regulatory framework. Water and Ecology. 3 (75), 54-62

14. Dregulo, A. M. and Bobylev, N. G. 2021. Heavy Metals and Arsenic Soil Contamination Resulting from Wastewater Sludge Urban Landfill Disposal. Polish Journal of Environmental Studies, 30(1),81-89.

15. Donatello S., Tyler M., Cheeseman C.R., 2010 EU landfill waste acceptance criteria and EU Hazardous Waste Derective compliance testing of incinerated sewage sludge ash. Waste Management. 30.,63-71

16. Kapoor V., Li X., Elk M., Chandran K., Impellitteri C.A., Santo Doming J. 2015. Impact of Heavy Metals on Transcriptional and Physiological Activity of Nitrifying Bacteria / Environmental Science \& Technology. 49 (22), 13454-13462

17. Kuuppo P., Tamminen T., Voss M., Schulte U. 2006 Nitrogenous discharges to the eastern Gulf of Finland, the Baltic Sea: Elemental flows, stable isotope signatures, and their estuarine modification. Journal of Marine Systems. 63. (3-4), 191-208

18. Luczkiewicz A. 2006. Soil and groundwater contamination as result of sewage sludge land application /Polish Journal of Environmental Studies. 15, 869-876.

19. Lee Y.W., Ong S.K., Sato C. 1997. Effects of heavy metals on nitrifying bacteria. Water Science \& Technology. 36(12), 69-74

20. Methodological recommendations on carrying out inventory of objects accumulated environmental damage. 2013. Federal service for supervision in the sphere of environmental management of the Russian Federation. Available on: http://old.rpn. gov.ru/node/5209

21. Naveen B.P., Sumalatha J., Malik, R.K. 2018. A study on contamination of ground and surface water bodies by leachate leakage from a landfill in Bangalore, India. Geo-Engineering 9, 27

22. O'Geen, A.T. 2013 Soil Water Dynamics. Nature Education Knowledge 4(5):9 https:// www.nature.com/scitable/knowledge/library/ soil-water-dynamics-103089121/

23. O'Kelly B.C. 2005. Sewage sludge to landfill: some pertinent engineering properties / Journal of the Air
\& Waste Management Association. 55(6), 765-771.

24. Przydatek, G., Kanownik, W. 2019. Impact of small municipal solid waste landfill on groundwater quality. Environmental Monitoring and Assessment. 191, 169

25. Report "Conducting state monitoring of the geological environment of St. Petersburg in 2017”. 2018. (Mineral, St. Petersburg). 1.40-68 (in Russian)

26. Rodionov V.Z., Dregulo A.M., Kudryavtsev A.V. 2019. Anthropogenic impact on the ecological state of rivers in the Leningrad region. Water and Ecology. 24(4):96-108.

27. Solovyova V.A. 1984. "Report on engineering-geological and hydrogeological mapping of the territory of Leningrad in m-Bah 1: 25000 and 1:50000 for justification of the General plan of development of the city taking into account the use of underground space, 1980-1984. Northern and North-Eastern parts of Leningrad", 157 p. (in Russian)

28. Song U., Lee E.J. 2010. Environmental and economical assessment of sewage sludge compost application on soil and plants in landfill // Resources, conservation and recycling. 54. 1109-1116

29. Spinosa L. 2007. Wastewater Sludge: A Global Overview of the Current Status and Future Prospects. Water Intelligence Online. 6. https://doi. org/10.2166/9781780402154

30. The Helsinki Convention. 1974. Available on: https://web.archive.org/web/20091111235043/ http://www.helcom.fi/Convention/en_GB/ convention/

31. Wang L.M., Zhang Y.M., Lian J.J., Chao J.Y., Gao Y.X., Yang F., Zhang L.Y. 2013. Impact of fly ash and phosphatic rock on metal stabilization and bioavailability during sewage sludge vermicomposting. Journal of Hazardous Materials, 136, 281-287.

32. Wei Y., Liu Y. 2005. Effects sewage sludge compost application on crops and cropland in a 3-year study. Chemosphere. 59, 1257-1265.

33. Zakhvataeva N.V. and Shelomkov A.S. 2013. Activated sludge as a managed ecological system/ Moscow. Expo Media-Press., 286 p. (in Russian)

34. Zeng L.X., Wang T., Ruan T., Liu Q., Wang Y.W., Jiang G.B. 2012. Levels and distribution patterns of short chain chlorinated paraffins in sewage sludge of wastewater treatment plants in China. Environmental Pollutions. 160, 88-94. 